Paedagogia Christiana

2/30 (2012) - ISSN 1505-6872

Aldona Zakrzewska*

Olsztyn

\title{
Edukacja religijna dzieci i młodzieży szkolnej okresu międzywojennego źródłem humanizacji życia społecznego
}

\section{Wprowadzenie}

Po I wojnie światowej katolicka pedagogika postrzegana była w Europie jako ta, która, poprzez głoszenie stałych wartości, z prymatem Boga i idei miłości, może przywrócić ład społeczny i doprowadzić do odrodzenia życia duchowego człowieka ${ }^{1}$. W Drugiej Rzeczypospolitej wiele środowisk podzielało ten pogląd. Feliks Araszkiewicz stwierdził nawet, że w odrodzonej Polsce religia stanowiła stosunkowo stały element ideału wychowania reprezentowanego przez wszystkie klasy rządzące ${ }^{2}$, co doprowadziło do tego, iż katolicka doktryna wychowawcza zaznaczyła swoje miejsce również w rzeczywistości edukacyjnej. Wynikało to także z faktu, iż w katolicyzmie dostrzegano potencjał zjednoczeniowy narodu polskiego, który po ponad 120 latach niewoli i odmiennej polityki prowadzonej wobec niego przez trzech różnych zaborców wymagał scalenia w duchu odzyskania tożsamo-

* Dr Aldona Zakrzewska, adiunkt na Wydziale Nauk Społecznych Uniwersytetu Warmińsko-Mazurskiego w Olsztynie.

${ }^{1}$ Por. J. Kuchta, Nowe kierunki i dażenia współczesnej katolickiej pedagogiki, Lwów 1939, s. 77-81.

2 Por. F. Araszkiewicz, Ideały wychowawcze Drugiej Rzeczypospolitej, Warszawa 1978, s. 275. 
ści narodowej i państwowej oraz poczucia odpowiedzialności społecznej. Wydaje się więc, że edukacja religijna dzieci i młodzieży szkolnej w Polsce międzywojennej odgrywała ważną rolę w szeroko pojętej humanizacji życia społecznego. Czy tak było rzeczywiście? Kto i w jaki sposób przyczynił się do zaistnienia w rzeczywistości edukacyjnej religii katolickiej, dostrzegając w niej źródło harmonii społecznej? W jakich obszarach edukacji religijnej i w jaki sposób podejmowano troskę o kształtowanie postaw społecznych? Czy prowadzona wśród dzieci i młodzieży edukacja religijna miała szansę pozytywnie oddziaływać na poprawę życia społecznego w obliczu narastającego w drugim dwudziestoleciu konfliktu między Kościołem katolickim a władzami państwowymi? Próba odpowiedzi na niniejsze pytania stanowi podstawę podjętych rozważań.

Na wstępie chcę również wyjaśnić, że rozpatrywana problematyka odnosi się do tych form edukacji religijnej, które ściśle związane były z religią rzymskokatolicką i oddziaływały na dzieci i młodzież na terenie szkół powszechnych i średnich. Pragnę też zaznaczyć, iż nie roszczę sobie prawa do przyjęcia jednoznacznych sądów i rozstrzygnięć. Prowadzone dociekania pozostawiam raczej na etapie pytań, tym bardziej, że przyjęte problemy nie wyczerpują w pełni zagadnienia wpływu edukacji religijnej na humanizację życia społecznego, które jest niezwykle złożone i wymaga wnikliwego oraz wielopłaszczyznowego badania. Stanowią więc one raczej prolog lub zachętę do podjęcia dalszych, pogłębionych studiów.

\section{Społeczna wartość nauczania i wychowania religijnego w poglądach pedagogów, Kościoła katolickiego i czynników wplywających na stanowienie prawa szkolnego}

Na początku przyjrzyjmy się pokrótce poglądom tych, którzy dostrzegali w nauczaniu i wychowaniu religijnym społeczne walory, dzięki którym W sposób pośredni lub bezpośredni wartości stanowiące podwaliny pedagogiki katolickiej miały możliwość stania się istotnym elementem edukacji dzieci i młodzieży, a w konsekwencji humanizacji życia społecznego czasów międzywojennych.

Ludwik Chmaj w Kierunkach i pradach pedagogiki współczesnej z 1938 roku zauważa, że zwolennicy wychowania chrześcijańskiego, również ci, którzy oddziaływali na międzywojenną teorię i praktykę pedagogiczną, dostrzegali w edukacji religijnej jedyne źródło uczłowieczenia kultury, oczyszczenia jej ze szkodliwych elementów, a także jej duchowego pogłębienia. Podkreślali przy tym, że prawdziwe wychowanie musi być w swej istocie 
chrześcijańskie, ponieważ „tylko religia Chrystusa rozgranicza bezwzględnie ducha od natury, a ustanawiając jednocześnie między nimi ścisły stosunek wychowawczy, zaprowadza ład wewnętrzny w duszy i dostarcza trwałej podstawy do pracy samowychowawczej"3.

Dostrzegali oni w nauczaniu i wychowaniu religijnym źródło pełni rozwoju człowieka, zaznaczając iż formułowane tu cele wychowawcze uwzględniają całego człowieka - jego ciało i duszę, jego życie doczesne i wieczne. Jest to system, który niewątpliwie jest nośnikiem humanizacji życia społecznego, gdyż „patrzy” na wszystko z punktu widzenia miłości Boga i bliźniego, a więc jest wolny od nienawiści, którą niejednokrotnie żywią wobec siebie jednostki, grupy społeczne, narody czy państwa. Kierując się niezmiennie ,pedagogiką Chrystusa”, wychodzi naprzeciw aktualnej rzeczywistości - aktualnym potrzebom, zaletom i wadom państwa, narodu, grupy społecznej czy jednostki ${ }^{4}$. Identyfikowali się tu oni w pełni z nauczaniem papieża Piusa XI zawartym w encyklice Divini Illius Magistri (O chrześcijańskim wychowaniu młodzieży) z 1929 rokus, określanej jako „,wielka karta” wychowania chrześcijańskiego ${ }^{6}$.

Wśród polskich teoretyków katolickiego wychowania religijnego, którzy z pewnością oddziaływali na rzeczywistość edukacyjną okresu międzywojennego, wyróżnia się przede wszystkim osoby duchowne. Znaleźli się tu między innymi: ks. Bronisław Kulesza, ks. Jan Kuchta, ks. Zygmunt Bielawski, o. Fryderyk Klimke, ks. Franciszek Sawicki, ks. Konstanty Michalski, ks. Karol Mazurkiewicz, ks. Michał Klepacz, ks. Walery Jasiński, ks. Wincenty Granat, ks. Jan Stepa, ks. Andrzej Krzesiński, o. Jacek Woroniecki, ks. Władysław Karasiewicz, ks. Stanisław Podoleński, ks. Nikodem Cieszyński, ks. Jan Ciemniewski, ks. Jan Salamucha, s. Barbara Żulińska, m. Janina Teresa Kalkstein, ks. Stanisław Dunin-Borkowski, ks. Walenty Gadowski, ks. Kazimierz Werbel, ks. Mieczysław Węglewicz, ks. Henryk Weryński, ks. Wacław Niemyski, Karol Górski, Ludwika Jeleńska, ks. Jan Fondaliński, Zygmunt Kukulski, ks. Zygmunt Choromański, o. Edward Kosibowicz, ks. bp Stanisław Adamski ${ }^{7}$. Wiele z tych osobistości wniosło znaczący wkład w rozwój oświaty i życia społecznego. Tutaj, z powodu ograniczeń edytorskich oraz z uwagi na podjętą problematykę wpływu edukacji

${ }^{3}$ L. Chmaj, Prady i kierunki w pedagogice XX wieku, Warszawa 1962, s. 440.

${ }^{4}$ Por. J. Kuchta, dz. cyt., s. 49-53.

${ }^{5}$ Por. Pius XI, Divini Illius Magistri, Rzym 1929, 58, 95, 98, 99, 100. [Numeracja na podstawie tekstu angielskiego zamieszczonego na stronie: www.vatican.va]

${ }^{6}$ Por. M. J. Żmichrowska, Edukacja w nauczaniu Kościoła, w: A. Kryński (red.), Ewangelizacja a edukacja w trzecim tysiacleciu, Częstochowa 2002, s. 149.

7 Por. J. Kuchta, dz. cyt., s. 89-94, 98-99, 127-142, 148. 
religijnej na humanizację życia społecznego, przyjrzę się jedynie poglądom ks. Zygmunta Bielawskiego (1877-1939), będącego znanym i poważanym profesorem katechetyki i pedagogiki chrześcijańskiej.

Ks. Z. Bielawski jako znawca nauki religii podkreślał, że chrześcijańskie wychowanie obejmuje wszystkie sfery ludzkiego życia, w tym również życia społecznego, aby ,je podnieść, nim kierować i udoskonalić wedle przykładu i nauki Zbawiciela"s. Wynika to z faktu, iż cel ogólny wychowania chrześcijańskiego zawiera w sobie także zadanie społeczne - przygotowanie wychowanka do podjęcia pracy na rzecz dobra i rozwoju społeczeństwa, w którym żyje9.

Bielawski ukazywał, że wychowanie w duchu chrześcijańskim nie wyłącza zadań świeckich (pod warunkiem ich etyczności), ale łączy w jedną całość cele indywidualne i społeczne: „Praca nad swym zbawieniem w królestwie Bożym na ziemi, to religijna strona naszego zadania życiowego; wypełnienie zaś obowiązków na obranych stanowiskach w służbie i dla rozwoju społeczeństwa, w którym żyjemy, to strona świecka jednego i tego samego zadania życiowego. Stąd też nie ma dwóch celów wychowawczych, obok siebie położonych: celu ziemskiego i wiecznego, ale jest jeden jedyny cel ogólny wychowania, łączący je w sobie"10. Bielawski zaznaczał przy tym, iż „pedagogika [...] religijna musi wytworzyć w duszy wychowanków prawdziwe zrozumienie przykazania miłości bliźniego [...] odnośnie do narodów i państw innych i całej ludzkości, jako też zrozumienie nie tylko obowiązków miłości, ale i sprawiedliwości wobec własnego państwa i form społecznych we własnym państwie"11.

W procesie wychowawczym Bielawski kładł szczególny nacisk na właściwe prowadzenie katechezy, która ma wyrabiać w wychowanku wartości religijno-moralne, gdyż religia chrześcijańska nierozerwalnie wiąże się z życiem etycznym, a katechetyka jest zobowiązana do tworzenia wartości etycznych w katechumenie. Stąd katechetykę określał on mianem pedagogiki religijno-moralnej (w skrócie - pedagogiki religijnej) $)^{12}$.

Kościół poprzez swoje nauczanie i działalność podzielał stanowisko Z. Bielawskiego i innych pedagogów, którzy w edukacji, w tym również religijnej, upatrywali źródeł pełni prawdziwej harmonii życia społecznego. Był wręcz przekonany, że bez religii nie można nikogo wychować na

\footnotetext{
${ }^{8}$ Z. Bielawski, Wychowanie religijne, Warszawa 1936, s. 27.

${ }^{9}$ Por. tamże, s. 26-27.

10 Tamże, s. 27.

11 Tamże, s. 29.

12 Por. tenże, Pedagogika religijno-moralna. (Katechetyka), Lwów 1934, s. 56-57.
} 
dobrego człowieka ${ }^{13}$. Stąd też ks. bp Józef Sebastian Pelczar przypominał u progu odzyskania przez Polskę niepodległości, iż od zawsze Kościół katolicki troszczy się, aby prawdą i prawem Chrystusa przeniknięty był każdy człowiek i wszystkie jego dziedziny życia, w tym również sfera wychowania szkolnego, a także życie społeczne ${ }^{14}$.

Biskupi zaznaczali przy tym, że zasadniczy cel i zadanie wychowania katolickiego, jakim jest uzdolnienie wychowanka do osiagnięcia chwały Bożej i szczęścia wiecznego, muszą być ściśle związane z celem drugorzędnym, a mianowicie podjęciem przez niego samodzielnej troski o swoje szczęście doczesne oraz wypełnieniem obowiązków swojego stanu i obowiązków wobec społeczeństwa ${ }^{15}$.

Wizję katolickiego wychowania dzieci i młodzieży w duchu humanizacji życia społecznego w sposób szczególny podkreślali ks. kard. Aleksander Kakowski oraz prymas Polski ks. kard. August Hlond. Kakowski domagał się wychowania młodych, jako przyszłości i kwiatu narodu, w duchu narodowym i katolickim, a szczególnie strzeżenia i osłaniania ich przed wpływami deprawującymi młode charaktery, ,wytwarzając ród karłów fizycznych i duchowych, a nie wielkich ofiarnych ludzi idei i czynu ku chlubie i chwale narodu"16. Hlond zaś stwierdzał, że jedynie etyka chrześcijańska jest w stanie zniwelować w życiu politycznym i publicznym szkodliwe przejawy przywar, które prowadzą do zdziczenia i nienawiści dzielącej obywateli na różne obozy zwalczające się wzajemnie ${ }^{17}$.

Działali też w okresie międzywojennym polscy społecznicy, politycy czy nauczyciele, którzy popierali postulaty Kościoła katolickiego, co było niezwykle istotne $\mathrm{z}$ uwagi na to, że poglądy znaczących w polityce partii i związanych z nimi zawodowych organizacji nauczycielskich oddziaływały na stanowienie prawa oświatowego.

Stanowisko Kościoła podzielały ugrupowania o charakterze chrześcijańsko-społecznym. Warto wspomnieć tu chociażby o Chrześcijańsko-Narodowym Stronnictwie Pracy (ChNSP) czy o Polskim Stronnictwie Chrześcijańskiej Demokracji (PSChD). Ich członkowie stwierdzali wręcz, że ,bez

13 Por. A. [Szymań]ski, Stanowisko religii w szkole. Wydanie drugie na nowo opracowane, Poznań-Warszawa 1921, s. 12.

14 Por. J. Szczepaniak, Troska Kościoła o nauczanie $i$ wychowanie religijne $w$ szkole w latach 1918-1927, Kraków 1997, s. 19.

15 Por. tamże, s. 19-20.

16 F. Araszkiewicz, dz. cyt., s. 163-164. Zob. Księga pamiqtkowa zjazdu katolickiego $w$ Warszawie 28-30 sierpnia 1926, s. 390-391.

17 Por. F. Araszkiewicz, dz. cyt., s. 164. Zob. A. Hlond, O chrześcijańskie zasady życia państwowego. List pasterski z 23 kwietnia 1932 r. 
religii nie może istnieć ani prawdziwa moralność, ani dobrobyt materialny, ani sumienna państwowość, ani w ogóle szczęśliwe życie społeczności”"18, stąd postulowali wprowadzenie nauki religii do szkół państwowych, pełne zrównanie szkół katolickich z państwowymi, a nawet stworzenie ustawowo uznawanej szkoły wyznaniowej ${ }^{19}$.

Podobne propozycje odnajdujemy również w programach prawicowych partii narodowych. Jedną z nich był Związek Ludowo-Narodowy (od 1929 roku Stronnictwo Narodowe ${ }^{20}$. Jednoznacznie za postulatami Kościoła opowiadało się również Stronnictwo Chrześcijańsko-Narodowe ${ }^{21}$.

Różne stanowisko prezentowali natomiast ludowcy. Przyznać należy jednak, że w zasadzie wszystkie ugrupowania ludowe dostrzegały użyteczność zasad etyki chrześcijańskiej nie tylko w życiu jednostki, ale również społeczeństw, z uwagi na propagowanie przez nią wartości ogólnohumanistycznych, idei pokoju czy zgodnego współżycia jednostek, społeczeństw, narodów i państw ${ }^{22}$. Jednak za wprowadzeniem w Polsce szkoły wyznaniowej opowiadało się jedynie Polskie Stronnictwo Katolicko-Ludowe ${ }^{23}$.

Jakie natomiast stanowisko wobec społecznej wartości edukacji religijnej prezentowało środowisko nauczycielskie? Wszak ono również, zgrupowane w zawodowe organizacje, wpływało na ustawodawstwo oświatowe. Niestety jedynie nieliczne organizacje, najczęściej o zasięgu lokalnym, popierały stanowisko Kościoła w sprawie obowiązkowego wprowadzenia we wszystkich szkołach nauki religii oraz szkoły wyznaniowej. Najprężniej wśród nich działały Stowarzyszenie Nauczycieli Polaków oraz Związek Dzielnicowy Stowarzyszeń Nauczycieli Polaków na Dawniejszy Zabór Pruski, obejmujące tereny Wielkopolski i Pomorza ${ }^{24}$. Związkiem zaś o zasięgu ogólnopolskim orientacji chrześcijańsko-narodowej, który powstał przy silnym poparciu Kościoła, było Stowarzyszenie Chrześcijańsko-Narodowe Nauczycielstwa Szkół Powszechnych w Polsce, rozwijające się głównie w województwach poznańskim, pomorskim, lwowskim i śląskim ${ }^{25}$.

18 A. Bełcikowska, Stronnictwa i zwiazki polityczne w Polsce, Warszawa 1925, s. 124.

19 Por. J. Szczepaniak, Troska, s. 41-42.

${ }^{20}$ Por. A. Bełcikowska, dz. cyt., s. 74-75; E. Maj, Religia i Kościół rzymskokatolicki w myśli politycznej Narodowej Demokracji (1918-1939), w: J. Jachymek (red.), Religia i Kościót rzymskokatolicki w polskiej myśli politycznej w 1919-1939, Lublin 1995, s. 47-49.

${ }^{21}$ Por. A. Bełcikowska, dz. cyt., s. 6-7.

${ }^{22}$ Por. J. Jachymek, Z. Tymoszuk, Religia i Kościót rzymskokatolicki w myśli politycznej ruchu ludowego (1918-1939), w: J. Jachymek (red.), dz. cyt., s. 134.

${ }^{23}$ Por. J. Szczepaniak, Troska, s. 43-46.

${ }^{24}$ Por. tamże, s. 62-63.

25 Por. tamże, s. 69-72. 


\section{Szkolna edukacja religijna w służbie humanizacji życia społecznego}

Wśród postulatów wychowawczych środowiska katolickiego istotne miejsce zajęło wychowanie religijno-moralne młodych. Miejscem, gdzie najczęściej spotykały się Kościół i państwo w dziele nauczania i wychowania dzieci i młodzieży dwudziestolecia międzywojennego, była szkoła.

W praktyce szkolnej Drugiej Rzeczypospolitej edukacja religijna najpełniej objawiała się w szkołach katolickich, w których cały proces dydaktyczny i wychowawczy przenikały wartości ewangeliczne. W pozostałych zaś obecna była $\mathrm{w}$ formie obowiązkowych zajęć szkolnych - lekcji nauki religii oraz praktyk religijnych, a także fakultatywnego angażowania dzieci i młodzieży w działalność szkolnych organizacji religijnych.

\section{a) Funkcjonowanie szkół katolickich}

Kościół katolicki dwudziestolecia międzywojennego opowiadał się za szkołą wyznaniowa. W prawdzie starania mające na celu powołanie państwowych szkół wyznaniowych nie powiodły $\operatorname{sie}^{26}$, jednak nie pozostały całkowicie daremne. Ich owocem było podjęcie intensyfikacji działań skutkujących zakładaniem i prowadzeniem przez poszczególne diecezje i zgromadzenia zakonne szkół katolickich.

W Polsce okresu międzywojennego placówki te funkcjonowały dzięki gwarancjom państwowym zawartym w konstytucjach z 17 marca 1921 roku i z 23 kwietnia 1935 roku (art. 117) ${ }^{27}$, potwierdzonym w konkordacie podpisanym przez rząd ze Stolicą Apostolską 10 lutego 1925 roku (art. 1 i 13) oraz Kodeksie Prawa Kanonicznego (kan. 1375, 1379 §1) ${ }^{29}$, a także w oparciu o regulacje ustawy o prywatnych szkołach oraz zakładach naukowych i wychowawczych z 11 marca 1932 roku $^{30}$.

${ }^{26}$ Por. J. Bugajska-Więcławska, Idea szkoły wyznaniowej w Polsce międzywojennej jako wyraz nauki społecznej Watykanu, „Res Historica” 12 (2000), s. 63.

27 Por. Konstytucja 17 marca 1921 r., Warszawa 1921; Konstytucja Rzeczypospolitej Polskiej z dnia 23 kwietnia 1935 roku, Lwów-Warszawa 1935.

${ }^{28}$ Por. Konkordat zawarty pomiędzy Stolica Apostolską a Rzeczypospolitą Polską, „Dziennik Ustaw RP” 72 (1925), poz. 501.

29 Por. Kodeks Prawa Kanonicznego, 1917.

30 Por. „Dziennik Ustaw RP” 33 (1932), poz. 343. 
Przewagę miały wśród nich szkoły prowadzone przez zakony, które w odrodzonej Polsce swobodnie pracowały w oparciu o własne posłannictwo i charyzmaty ${ }^{31}$. W 1937 roku zakony zarządzały 390 szkołami katolickimi $^{32}$. Zasięg ich oddziaływania w porównaniu do szkół państwowych był niewielki, bo obejmował $0,27 \%$ szkół powszechnych, 5,2\% zawodowych i około $9 \%$ średnich ogólnokształcących ${ }^{33}$. Mimo to, zdaniem niektórych historyków wychowania, szkolnictwo katolickie stanowiło w Drugiej Rzeczypospolitej jeden z filarów jej systemu edukacji ${ }^{34}$, głównie ze względu na jakość kształcenia i wychowania. Szkoły katolickie wyróżniały się spośród innych przede wszystkim tym, że oprócz troski o wysoki poziom nauczania zapewniały trwałe i mocne podstawy moralne, przeniknięte czystymi i spójnymi zasadami, co w kształtowaniu postaw społecznych odznaczających się pełnym humanizmem stanowiło niezwykle istotną rolę. Za kluczowe zadanie szkoły te przyjmowały więc kształtowanie charakteru, zwracając uwagę nie tylko na kształcenie umysłu, ale również serca i woli przez rozwijanie szlachetnych uczuć i zdolności poświęcania się dla drugiego człowieka. Kładziono w nich także nacisk na wychowanie społeczne i patriotyczne oraz kształtowano postawę rzetelnego podejścia do pracy ${ }^{35}$.

Podkreśla się, iż twórczemu oddziaływaniu na wolę uczniów sprzyjało kilka czynników obecnych w szkołach katolickich. Po pierwsze, realizowany w nich program nauczania w zakresie przedmiotów nadobowiązkowych, między innymi obecność śpiewu, chóru, orkiestry. Po drugie, nieustanne oddziaływanie na wolę uczniów - nie tylko na wszystkich zajęciach lekcyjnych i pozalekcyjnych, ale również podczas ich mieszkania w internacie. Po trzecie, stawianie uczniom wysokich wymagań i systematyczne ich ocenianie. Po czwarte zaś, obecność różnorodnych organizacji naukowych, kulturalnych, religijnych czy sportowo-rekreacyjnych, dzięki czemu rozwijały się

31 Por. W. W. Żurek, Szkolnictwo zakonne w okresie międzywojennym na tle prądów epoki, w: E. Walewander (red.), Katolicka a liberalna myśl wychowawcza w Polsce w okresie międzywojennym - zagadnienia wybrane, Lublin 2000, s. 335.

32 Por. A. Maj, Szkolnictwo katolickie w III RP (1989-2001), Warszawa 2002, s. 175.

33 Por. B. Gromada, Szkoty sióstr nazaretanek w Warszawie w latach 1919-1944, ,Roczniki Humanistyczne" 2 (1999), s. 218.

34 Por. Ł. Kazimierczak, U Pana Boga w ławce, „Przewodnik Katolicki” 8 (2005), s. 10; B. Bilicka, Nauczyciel szkoty katolickiej. Wychowanie do dialogu i tolerancji, „Ateneum Kapłańskie" 149 (2007), s. 465.

35 Por. W. W. Żurek, dz. cyt., s. 360; L. Albański, Dorobek pedagogiczny szkolnictwa salezjańskiego w Polsce, w: T. Jałmużna, W. Leżańska (red.), Szkolnictwo niepubliczne w Polsce i w Europie w XX wieku, Łódź 2002, s. 223; R. Grzybowski, Prywatne szkoły ogólnokształcace w Gdyni w latach 1920-1939, w: T. Jałmużna, W. Leżańska (red.), dz. cyt., s. 147-149. 
u dzieci i młodzieży nie tylko indywidualne zainteresowania i zdolności, ale również potrzeba podjęcia pracy społecznej na rzecz innych ${ }^{36}$.

Objawiający się tu obraz polskiej szkoły katolickiej dwudziestolecia międzywojennego spójny jest z jej wizją ukazaną w 1929 roku przez Piusa XI we wspomnianej już encyklice Divini Illius Magistri. Papież zauważył, że szkoła katolicka pełni jak najbardziej misję społeczną, ponieważ wychowanie w oparciu o zasady katolickie daje gwarancję ukształtowania dobrych obywateli, miłujących swoją Ojczyznę i lojalnych wobec władzy państwowej ${ }^{37}$. Można powiedzieć, że funkcjonowanie szkoły katolickiej postrzegane przez niego w kategorii wielkiego dobra społecznego, które służy poszczególnym jednostkom, społeczności i kulturze, a także pokojowi i budowaniu wspólnoty $^{38}$, a więc służy humanizacji życia społecznego, bliskie było rzeczywistości omawianych czasów, jeśli nie w wymiarze ilościowym (ze względu na niewielką liczbę szkół), to bezsprzecznie jakościowym. Chociaż przyznać należy, że pewien cień na pozytywny społeczny odbiór szkolnictwa katolickiego mogła rzucać prowadzona przez Kościół batalia o szkołę wyznaniową ${ }^{39}$, która niosła ze sobą zacięte i ostre polemiki z jej przeciwnikami ${ }^{40}$.

\section{b) Obecność religii w szkole mieszanej i świeckiej}

Ks. Antoni Szymański zaznaczał, że w szkole naczelne miejsce powinna zajmować nauka religii, ,człowiek bowiem nie jest jestestwem samoistnym, nie ma w sobie samym zasad swego istnienia, ale jest tworem Bożym"41.

${ }^{36}$ Por. W. W. Żurek, dz. cyt., s. 360-361.

${ }_{37}$ Por. K. Skoczylas, Środowisko wychowawcze szkoły katolickiej, „Ateneum Kapłańskie” 149 (2007), s. 448. Zob. Pius XI, dz. cyt., 80-83.

${ }_{38}$ Por. M. Nowak, Program wychowawczy szkoty katolickiej i jego konstruowanie, „Ateneum Kapłańskie" 149 (2007), s. 427.

${ }^{39}$ Próby wprowadzenia szkoły wyznaniowej podejmowane były przez Kościół przede wszystkim przed uchwaleniem konstytucji marcowej (1921 r.) i kwietniowej (1935 r.) oraz przed reformą szkolną z 1932 r. Por. J. Szczepaniak, Troska, s. 33-35, 127-163; tenże, Episkopat w obronie katolickiego charakteru polskiej szkoty 1927-1937, Kraków 2000, s. 105-130.

${ }^{40}$ Do uchwalonej konstytucji z 17 marca 1921 r., w której nie uwzględniono szkoły wyznaniowej, większość biskupów odniosła się krytycznie, w dość ostrych słowach. Biskup przemyski w liście otwartym, skierowanym do posłów swojej diecezji, pisał: „Przeciwnicy religii, uszykowani w partii socjalistycznej i w związkach radykalnych, zamiast opamiętać się, zapowiadają śmiało, że chcą przeprowadzić rozdział Kościoła i państwa, a szkoły zeświecczyć, to jest, wyrugować z nich naukę religii, aby przy pomocy nauczycieli bez wiary - a takich niestety nie brak - wychować młode pokolenie w ateizmie". Cyt. za: J. Szczepaniak, Troska, s. $155-156$.

${ }^{41}$ A. [Szymań]ski, dz. cyt., s. 25. 
Polski parlament także dostrzegł w nauce religii wartość pomocną i ważną w wychowaniu młodego pokolenia. Wprawdzie odrzucił on projekt zakładający utworzenie szkoły wyznaniowej, o którą walczył Kościół katolicki, stąd polska państwowa szkoła była laicka, ale zagwarantował w niej prawo nauczania religii ${ }^{2}$. Obowiązkowe nauczanie religii (w większości w liczbie 2 godzin tygodniowo) sankcjonowały w pierwszym rzędzie konstytucje marcowa oraz kwietniowa (art. 120). Obligowały one do objęcia nauką religii dzieci i młodzież poniżej 18 lat te szkoły, które w całości lub w części utrzymywane były przez państwo lub jednostki samorządowe ${ }^{43}$. Zobowiązania owe nakładały na wszystkie szkoły publiczne również postanowienia konkordatu (art. XIII) ${ }^{44}$ oraz okólnik ministra WRiOP Kazimierza Bartla z 9 grudnia 1926 roku (§1) - poszerzający zasadę obowiązkowości nauki religii o wszystkie szkoły prywatne, posiadające uprawnienia szkół państwowych lub publicznych ${ }^{45}$.

Biorąc pod uwagę podjętą w niniejszych rozważaniach problematykę, warto zaznaczyć, że program nauczania religii, zgodnie z deklarowanym przez Kościół wychowaniem religijno-moralnym, obejmował swoim zakresem zagadnienia etyczne, które znalazły się tuż po tematyce dogmatycznej ${ }^{46}$. Stad też przy precyzowaniu celów nauczania religii w programach dla szkół powszechnych umieszczono na pierwszym miejscu ,nadanie wychowaniu szkolnemu charakteru religijno-moralnego", zaznaczając dalej, iż nauka religii ma prowadzić nie tylko do poznania i utrwalenia prawd religijnych, rozbudzenia uczuć religijnych, gotowości do służby Bożej i udziału w obrządkach katolickich czy podejmowania żywego związku z Kościołem, ale także do wyrobienia prawego sumienia i umocnienia woli ${ }^{47}$, co bez wątpienia pozwalało na podjęcie szeregu zadań ukierunkowanych na podniesienie jakości życia społecznego. Wprawdzie w szkołach średnich cel nauczania religii sformułowany został w sposób lakoniczny i mówił jedynie o ukształtowaniu światopoglądu katolickiego i wyrobieniu chrześcijańskiego charak-

${ }^{42}$ Por. J. Bugajska-Więcławska, dz. cyt., s. 63.

${ }_{43}$ Por. Konstytucja 17 marca; Konstytucja Rzeczypospolitej.

${ }^{44}$ Por. Konkordat, poz. 501.

${ }^{45}$ Por. Rozporzqdzenie MWRiOP z dnia 9 grudnia 1926 r. o nauce szkolnej religii katolickiej, „Dziennik Ustaw RP” 1 (1927), poz. 9.

${ }^{46}$ Por. L. Grochowski, Wychowanie religijne katolickie w szkołach II Rzeczypospolitej lat dwudziestych. Treści i funkcje, w: E. Walewander (red.), dz. cyt., s. 245.

${ }^{47}$ Por. tamże, s. 246. Zob. Program nauki w szkołach powszechnych siedmioklasowych. Religia. 
teru $^{48}$, to jednak dzięki temu dawał duże możliwości podjęcia działań wychowawczych na polu kształtowania postaw w dziele służby humanizacji życia społecznego.

Wśród zagadnień etycznych podejmowano również problematykę społeczno-polityczną, dotykając głównie obowiązków człowieka względem innych ludzi, narodu, państwa i Kościoła, które mogą być wypełniane dzięki praktykowaniu cnót społecznych - przede wszystkim miłości, sprawiedliwości, pokory i posłuszeństwa. Ich interpretacja ukierunkowana była jednak między innymi na obronę własności prywatnej, panującego ustroju i gospodarki wolnorynkowej z jednoczesnym uznaniem nierówności społecznej jako naturalnej struktury ${ }^{49}$. Chociaż przyznać należy, że przez wskazywanie młodym miłości jako właściwego narzędzia w stosunkach społecznych dążono do zacierania konfliktów klasowych, zachęcając ich do podejmowania dzieł miłosierdzia w duchu ofiary i wyrzeczenia, wprowadzania w życie idei sprawiedliwości społecznej, słusznej oceny klas przeciwstawnych sobie w poglądach i działaniach czy współczującego i wielkodusznego spojrzenia na wady społeczne ${ }^{50}$.

W ramach edukacji religijnej dzieci i młodzieży ceniono także ukazywanie im ideałów wychowawczych. Ważną w podejmowanej tutaj refleksji wydaje się kwestia, iż na pierwszym miejscu stawiano ideał katolika, nie tylko silnie związanego z formami kultowo-dewocyjnymi, ale również wyrobionego moralnie, $\mathrm{z}$ odpowiednio ukształtowanym charakterem ${ }^{51}$.

Istotny z punktu widzenia omawianego problemu jest również fakt, iż pedagodzy katoliccy zasadniczo przychylnie nastawieni byli do wchodzących na „arenę” edukacyjną ideałów wychowawczych i starali się wprowadzać ich elementy na lekcjach religii. W świetle nauki Kościoła ukazywali ich dodatnie i ujemne strony. Kiedy „królował” ideał wychowania narodowego, podkreślali, iż chcąc pracować z młodzieżą realnie w duchu religijnym nie wolno pomijać zalet i braków charakteru narodowego. Zachęcali więc do równoległej pracy nad duszą polską i nad jej przymiotami religijno-moral-

48 Por. L. Grochowski, dz. cyt., s. 246. Zob. Program gimnazjum państwowego. Religia; Program nauki w państwowych seminariach nauczycielskich. Religia.

49 Por. L. Grochowski, dz. cyt., s. 250. Zob. W. Kalinowski, Etyka. Podręcznik dla klas wyższych, Poznań-Warszawa 1928, cz. 2: Etyka szczegółowa 4. Życie społeczne; Program nauki w państwowych seminariach, s. 6-10.

50 Por. L. Grochowski, dz. cyt., s. 251. Zob. B. Żulińska, Kilka słów o wychowaniu społecznym, „Miesięcznik Katechetyczny i Wychowawczy” 8 (1925), s. 305-315.

51 Por. L. Grochowski, dz. cyt., s. 254. Zob. Program nauki w szkołach powszechnych, s. 3; Program gimnazjum, s. 2; Program nauki w państwowych seminariach, s. 1 . 
nymi ${ }^{52}$. Tak było również wobec wychowania państwowego. Ks. K. Jędrzejewski podkreślał, że między nim a wychowaniem religijno-moralnym nie ma zasadniczej sprzeczności. Konflikt zaś może zaistnieć wówczas, kiedy państwo pod płaszczem przygotowania młodzieży do współżycia i współpracy w ramach organizacji państwowej narzucać będzie ideologię i etykę niezgodną z zasadami moralnymi ${ }^{33}$. Ks. J. Rozkwitalski, ceniony w ówczesnym czasie wykładowca pedagogiki i katechetyki, uważał, że odnośnie wychowania obywatelsko-państwowego należało na gruncie nauki religii poruszyć przede wszystkim problem katolickiej koncepcji państwa, a także obowiązku współpracy państwa i Kościoła w sprawach moralności publicznej, bezpieczeństwa obywateli, zapewnienia im godziwych warunków życia oraz rozwoju kultury duchowej i materialnej ${ }^{54}$.

Oczywiście, zdawano sobie sprawę, że dla właściwego rozwoju człowieka, w tym jego dojrzewania społecznego, potrzebne jest, oprócz wykształcenia religijno-moralnego, również chrześcijańskie wychowanie. Za istotny element tego wychowania uznawano przyzwyczajanie uczniów do praktyk religijnych. Pojawiały się nawet głosy żądające wprost łączenia nauki religii z praktykami religijnymi, a od 1928 roku wiązania religii z tak zwanym ruchem liturgicznym ${ }^{55}$.

Praktyki religijne (msze, spowiedź i komunia św., nabożeństwa, rekolekcje, modlitwy) wprowadzane były w szkołach już od początku uzyskania przez Polskę niepodległości, z czasem zaś zyskały wobec młodzieży katolickiej status zajęć obowiązkowych - częściowo na mocy zarządzenia ministra WRiOP Kazimierza Kumanieckiego z 29 listopada 1922 roku $^{56}$, a w pełni na podstawie wspominanego już okólnika K. Bartla z końca 1926 roku $^{57}$ (§7).

Kościół dostrzegał w nich walory wychowawcze. J. Woroniecki stwierdzał nawet, iż wykład w ramach nauki religii powinien być podporządkowany nabożeństwu, ponieważ na odcinku praktyk religijnych buduje się ideał życia chrześcijańskiego ${ }^{58}$, obejmujący przecież nie tylko zasady światopo-

52 Por. T. D. [T. Długosz], Nasze wytyczne, „Miesięcznik Katechetyczny i Wychowawczy” 4-6 (1922), s. 98.

${ }^{53}$ Por. K. Jędrzejewski, Podstawy wychowania państwowego, Warszawa 1932, s. 17.

${ }^{54}$ Por. J. Szczepaniak, Episkopat, s. 74.

55 Por. L. Grochowski, dz. cyt., s. 247.

${ }^{56}$ Por. K. Trzebiatowski, Szkolnictwo powszechne w Polsce w latach 1918-1932, Wrocław-Warszawa-Kraków 1970, s. 97.

${ }^{57}$ Por. L. Grochowski, dz. cyt., s. 244, 257.

58 Por. J. Woroniecki, Zdolność wychowawcza szkoły publicznej i jej granice, „Miesięcznik Katechetyczny i Wychowawczy" 5-7 (1924), s. 71-72. 
glądu i żywe związki z Kościołem, ale również postawę etyczną - tak istotną dla ładu i harmonii życia społecznego.

Rzeczywiście praktyki religijne, wyrażające się szczególnie w formie kazań, przemówień (nauk rekolekcyjnych oraz egzort wygłaszanych podczas nabożeństw), mogły odgrywać istotną funkcję poznawczą i wychowawczą. W powiązaniu zaś ze szkolnym wkładem religii uwydatniały teoretyczne i praktyczne wnioski wynikające z problematyki i zasad religii. Wydaje się, że w obliczu omawianego problemu istotną wartość miały zwłaszcza nauki rekolekcyjne z uwagi na to, iż ukierunkowane były na wskazywanie młodym dróg i sposobów wyrobienia charakteru oraz uzyskania doskonałości moralnej ${ }^{59}$.

Nie można tu również pomijać niezwykle istotnej roli wszelkich praktyk religijnych, traktowanych jako nadprzyrodzony środek ${ }^{60}$ wyrabiania silnej woli u dzieci i młodzieży, mogącej być kluczem humanizacji życia społecznego. Ks. Stanisław Podoleński, dostrzegając w modlitwie, spowiedzi czy komunii świętej tę siłę sprawczą, stwierdził: „któż może skuteczniej uszlachetnić i wzmocnić wolę, jeśli nie sam jej Stwórca, znający dobrze ludzką słabość. Człowiek bez Boga, bez wiary w życie wieczne mógłby rzec sobie: Po cóż nam walczyć, czemu się przezwyciężać, czyż nie lepiej używać? Ale w świetle prawd wiecznych cała rzecz przedstawia się inaczej i daje silnego bodźca do pracy nad wyrobieniem woli i charakteru" $"$.

Niestety, w sprawach nauczania i wychowania religijnego między władzami szkolnymi a kościelnymi zachodziły spory, które negatywnie oddziaływały na edukację religijną dzieci i młodzieży szkolnej oraz jej wpływ na humanizację życia społecznego. Jedną z ważnych kwestii spornych były nominacje katechetów. Poważnym problemem, w zasadzie przez cały okres międzywojenny, była sprawa stałych etatów katechetycznych w szkołach powszechnych, co jest niezwykle istotne dla właściwego oddziaływania pedagogicznego każdej dziedziny kształcenia i wychowania. Starania zaś biskupów o powoływanie nowych katechetów etatowych, szczególnie w latach trzydziestych, spotykały się często z odmową, co tłumaczono kryzysem ekonomicznym, chociaż działania te nie przynosiły znaczących oszczędności budżetowych ${ }^{62}$. Raz po raz pojawiały się też lokalne zadrażnienia odnośnie do obsady etatów nauczycieli religii osobami świeckimi, łącznie z przypad-

59 Por. L. Grochowski, dz. cyt., s. 259.

${ }^{60}$ Por. J. Grochocki, Nauka religii a wychowanie państwowo-obywatelskie, „Miesięcznik Katechetyczny i Wychowawczy" 1 (1931), s. 8-9.

${ }^{61}$ Cyt. za: J. Wacławski, Wola -jako czynnik wychowawczy, „Miesięcznik Katechetyczny i Wychowawczy" 6-7 (1925), s. 276.

${ }^{62}$ Por. J. Szczepaniak, Episkopat, s. 146-147. 
kami odbierania księżom prawa nauczania religii czy usuwania prefektów bez rzeczowych powodów i bez porozumienia z biskupem diecezji ${ }^{63}$. Zdarzały się także sytuacje, kiedy inspektorzy szkolni starali się nie dopuścić duchowieństwa parafialnego do nauczania religii w szkole powszechnej. Umożliwiał im to wydany 8 lipca 1935 roku okólnik Ministerstwa WRiOP, zgodnie z którym, jeżeli z tylko sobie znanych powodów nie chcieli oni korzystać z gotowości podjęcia katechezy przez księży, mieli prawo wnieść do kurii prośbę o wydanie misji nauczania religii dla nauczycieli świeckich ${ }^{64}$. Jeśli kuria nie nadesłała misji, wówczas zdarzało się, że w szkole nie było religii, bowiem władze szkolne nie wyznaczyły nikogo z księży; czasami zaś katechizowanie odbywało się poza szkołą ${ }^{65}$.

Kolejną istotną sprawą sporną, zaistniałą między rządem a Kościołem, negatywnie wpływającą w ramach oddziaływania edukacji religijnej na humanizację życia społecznego, były trudności w określeniu zasad kwalifikacji koniecznych do podjęcia obowiązków dla nauczycieli religii w szkołach powszechnych. Miały one być ustalone w osobnym okólniku, zgodnie z postanowieniem rozporządzenia prezydenta Ignacego Mościckiego z 6 marca 1928 roku o kwalifikacjach zawodowych nauczycieli szkół powszechnych. Niestety, określenie tych norm odwlekało się aż do 1937 roku, co strona rządowa wykorzystała w konflikcie pomiędzy Kościołem a państwem na początku lat trzydziestych, nie zważając na protesty Kościoła, który podkreślał, że uczący w szkołach wszystkich typów mają ustalane kwalifikacje na mocy obowiązującego konkordatu ${ }^{66}$. Władze szkolne skrupulatnie owo niedomówienie spożytkowały, przyznając niejednokrotnie katechetom niższe uposażenia czy wymagając od nich złożenia egzaminu praktycznego, sprawdzającego ich umiejętności pedagogiczne ${ }^{67}$.

Na napięcia w stosunkach państwa i Kościoła wpływały też inne problemy ściśle wiążące się z kwestią nominacji i kwalifikacji katechetów. Znalazły się wśród nich głównie redukcja godzin nauki religii oraz obniżenie zapłaty księżom katechetom. Szczególnie zmniejszenie ilości godzin nauczania religii, co miało miejsce w szkołach byłego zaboru pruskiego ${ }^{68}$ oraz szkołach

63 Por. tamże, s. 149.

64 Por. tamże, s. 157.

65 Por. tamże, s. 157-158.

66 Por. tamże, s. 168-169, 174.

67 Por. tamże, s. 170-172.

68 Po odzyskaniu przez Polskę niepodległości na terenach byłego zaboru pruskiego liczba godzin nauki religii pozostała taka, jaka była przed wybuchem I wojny światowej - w pierwszej klasie szkoły ludowej 3 godziny, a w pozostałych po 4. Wprawdzie w 1922 r. prymas E. Dalbor wyraził zgodę na nauczanie religii w wymiarze 2 godzin, zastrzegając jednak, że w diecezjach 
zawodowych $^{69}$, a także redukcja ilości godzin religii faktycznie udzielanych przez księży w szkołach powszechnych, co dokonywało się przez łączenie oddziałów klasowych (nawet do 90 uczniów) ${ }^{70}$, poddaje w watpliwość jakość edukacji religijnej, a więc i oddziaływania religii na kształtowanie właściwych postaw społecznych.

Do spięć między urzędnikami ministerialnymi a Kościołem dochodziło także na płaszczyźnie tworzenia programów i podręczników do nauki religii po roku 1932. Przedstawione przez ministerstwo WRiOP pierwsze projekty programu wymagały zdaniem biskupów i księży prefektów zmian, między innymi uwzględnienia istotnej dla wychowania społecznego zasady łączności wiary i moralności. Negocjacje trwały na tyle długo, że do porozumienia obie strony doszły w roku 1935 - w sprawie programu do gimnazjów ogólnokształcących z polskim językiem nauczania, zaś w sprawie liceum dopiero W roku $1938^{71}$.

Napięcia niosło ze sobą również wypełnianie przez uczniów praktyk religijnych. Szczególnie okólnik Bartla, który formalnie ponawiał zobowiązanie do czuwania nad ich wykonywaniem nie tylko prefektów, ale również dyrekcję i nauczycieli szkół, wywoływał niejednokrotnie niezadowolenie opinii społecznej (głównie posłów ugrupowań lewicowych), a w konsekwencji powstawanie niezbyt dobrych stosunków między kadrą pedagogiczną a duchowieństwem ${ }^{72}$.

\section{c) Działalność religijnych organizacji szkolnych}

Kościół wykorzystywał do potrzeb wychowawczych nie tylko ćwiczenia religijne, ale też szkolne organizacje religijne. Wspomagały one przede wszystkim wychowanie religijne, ale przyznać należy, że każda z nich, ćwicząc dzieci i młodzież w czynnej miłości bliźniego ${ }^{73}$, pośrednio służyła również humanizacji życia społecznego. Wynikało to także z faktu, że wszystkie katolickie organizacje młodzieży szkolnej miały w zasadzie wspólny cel,

zachodnich zachowany zostanie zwyczaj sprzed I wojny światowej. Niestety po przewrocie majowym władze oświatowe starały się to zmienić. Por. tamże, s. 182-192.

${ }^{69}$ Por. tamże, s. 193-204.

${ }^{70}$ Por. tamże, s. 204-212.

${ }^{71}$ Por. tamże, s. 231-243.

72 Por. tenże, Troska..., s. 218.

${ }^{73}$ Por. J. Gajkowski, Organizacje religijne wśród młodzieży, w: Pamiętnik IV-go ogólnego Zjazdu Ks. Ks. Prefektów Królestwa Polskiego w Warszawie w dniach 20, 21 i 22 czerwca 1917, Warszawa 1917, s. 315. 
a mianowicie wspieranie w kształtowaniu młodych na czynnych członków społeczności ludzkiej w oparciu o idee chrześcijaństwa ${ }^{74}$.

Szkolne organizacje religijne w swoich założeniach wychowawczych i strukturze dostosowane były do faz rozwojowych i wieku swoich członków. W szkołach powszechnych przodowała popierana przez Kościół Krucjata Eucharystyczna (powołana w Polsce od 1925 roku) oraz Papieskie Dzieło Świętego Dziecięctwa Pana Jezusa, zaś w szkołach średnich Sodalicja Mariańska $^{75}$. Podkreślić należy, że stowarzyszenia te, biorąc pod uwagę ich wpływ na humanizację życia społecznego, kładły duży nacisk na wyrobienie swych członków w cnotach. Dlatego też wychowanie proponowane przez Krucjatę Eucharystyczną nie opierało się tylko na założeniach teoretycznych katolickiej myśli wychowawczej, ale zawierało propozycje konkretnych zachowań i norm postępowania $\mathrm{w}$ celu rozwinięcia w młodych również takich cech, jak: ofiarność, obowiązkowość, karność, gospodarność, wytrwałość, pracowitość, dzielność, czynną miłość bliźniego ${ }^{76}$. W organizacji tej zwracano też uwagę na kształtowanie postawy patriotycznej swoich członków, podejmując próbę wychowania obywatelskiego łączącego idee narodu i państwa $^{77}$. Poza tym Dzieło Świętego Dziecięctwa, jako organizacja misyjna, uczyło w sposób szczególny miłości bliźniego, miłosierdzia, odmawiania sobie na rzecz drugiego i oszczędności. Sodalicja Mariańska zaś przeistoczyła się na początku lat dwudziestych w związek religijno-społeczny ${ }^{78}$, o czym świadczy różnorodność zakładanych w niej sekcji, wśród których znalazły się i takie, których cele ściśle korespondowały z wymiarem społecznym jej działań, na przykad dobroczynna, towarzyska, sportowa, czytelnicza $^{79}$. Ks. Józef Winkowski określał Sodalicję wprost szkołą charakterów, prawdziwego życia społecznego i głębokiej przyjaźni ${ }^{80}$. Ustawy Sodalicji Mariańskiej Uczniów Szkót Średnich w Polsce podkreślając, że dąży ona

${ }^{74}$ Por. [F.] de Ville, Katolicka organizacja młodzieży szkolnej, w: Księga pamiątkowa, s. 206-207.

${ }^{75}$ Por. J. Szczepaniak, Troska, s. 264, 271; L. Grochowski, dz. cyt., s. 264-268; J. Szczepaniak, Episkopat, s. 219.

${ }^{76}$ B. Topij-Stempińska, Działalność edukacyjna Krucjaty Eucharystycznej w Polsce międzywojennej, Kraków 2009, s. 107-121, 181-222.

77 Tamże, s. 147-179.

${ }^{78}$ Por. M. Wiśniewski, O zrzeszeniach młodzieży, „Miesięcznik Katechetyczny i Wychowawczy" 1-3 (1922), s. 9.

${ }^{79}$ Por. J. Szczepaniak, Troska, s. 267, 271-272; L. Grochowski, dz. cyt., s. 265-268; J. Szczepaniak, Episkopat, s. 219-221.

${ }^{80}$ Por. J. Winkowski, Z naszej dziedziny. IV. Sodalicja Mariańska w szkole średniej, „Miesięcznik Katechetyczny i Wychowawczy” 6-7 (1919), s, 172. 
do wyrobienia młodych, którzy ,zobowiązują się spełniać jak najlepiej i jak najsumienniej przede wszystkim obowiązki katolika i dobrego syna Ojczyzny, następnie dobrego członka rodziny, wzorowego ucznia i kolegi" 81 , wskazują wyraziście, że organizacja ta zakładała aktywne uczestnictwo w zaprowadzaniu w społeczeństwie ładu i harmonii.

Początkowo przy zakładaniu stowarzyszeń religijnych Kościół miał pełną swobodę, chociaż niestety wielu duszpasterzy i nauczycieli nie była tym zainteresowana, a nawet okazywała swoją niechęć, co szczególnie było widoczne przy odradzaniu się ruchu sodalicyjnego ${ }^{82}$. Władze oświatowe nie czyniły jednak trudności i powoli stowarzyszenia religijne rozwijały się. Uznaje się, że Krucjata Eucharystyczna stała się po kilku latach swego istnienia główną, obok harcerstwa, organizacją dzieci i młodzieży, bo w 1931 roku obejmowała swoim zasięgiem około 20 tys. dzieci zgrupowanych w ponad 300 kołach $^{83}$. Nieustanną tendencję wzrostową przedstawiało Dzieło Świętego Dziecięctwa, dzięki czemu w 1925 roku skupiało ono 120 tys. członków w 592 kołach $^{84}$. Znacznie wolniej, ale równie pomyślnie, rozwijały się sodalicje - w 1932 roku było ich 246 z około 11 tys. uczniów ${ }^{85}$.

Niestety, rozwój szkolnych organizacji religijnych uległ zahamowaniu po przewrocie majowym. Przyczyniły się do tego dwa rozporządzenia. Pierwszym z nich był okólnik z 3 września 1927 roku, który zakładał uzyskanie zgody dyrektora szkoły średniej na założenie i prowadzenie jakiejkolwiek organizacji szkolnej ${ }^{86}$. Drugim zaś zarządzenie prezydenta RP z 27 października 1932 roku, które zakazywało dzieciom i młodzieży należenie do kółek i organizacji pozaszkolnych. Na ich podstawie wielu inspektorów i dyrektorów, szczególnie szkół powszechnych, wydało postanowienia zabraniające działalności stowarzyszeń religijnych w szkole, a nawet należenia do organizacji przyparafialnych. Niektórzy natomiast rozpoczęli ingerencję w ich działalność, głównie sodalicji, przez domaganie się przyłączenia jej do związku innych organizacji szkolnych czy przedstawiania szczegółowych sprawozdań lub podjęcie kontroli przez osobistą lub delegacyjną obecność

${ }^{81}$ Tenże (oprac.), Ustawy Sodalicji Mariańskiej Uczniów Szkół Średnich w Polsce, Zakopane 1931, s. 12-13.

82 Por. J. Szczepaniak, Troska, s. 264-266.

83 Por. L. Grochowski, dz. cyt., s. 265.

84 Por. J. Szczepaniak, Troska, s. 271.

85 Por. tenże, Materiaty $i$ studia do dziejów nauczania i wychowania religijnego, Kraków 2000, s. 204.

${ }^{86}$ Por. Okólnik MWRiOP w sprawie zakładania kółek i zrzeszeń młodzieży szkót średnich ogólnokształcacych, seminariów nauczycielskich i szkół zawodowych, „Dziennik Urzędowy MWRiOP” 11 (1927), poz. 183. 
nauczycieli świeckich na jej zebraniach ${ }^{87}$. Przychylność władz oświatowych wobec szkolnych organizacji religijnych powróciła dopiero w latach 19361937, po zakończeniu rozmów podjętych z nimi przez Episkopat w sprawie podstaw prawnych ich funkcjonowania ${ }^{88}$. W obliczu przytoczonych tu problemów trudno jest jednoznacznie stwierdzić, czy wpływ szkolnych organizacji religijnych na humanizację życia społecznego czasów Drugiej Rzeczypospolitej był znaczny.

\section{Zakończenie}

Przeświadczenie, że w edukacji religijnej tkwi ogromny potencjał wychowawczy, w tym także na płaszczyźnie humanizacji życia społecznego, stanowiło inspirację i siłę wszelkich działań, jakie podejmował Kościół, wprowadzając ją w obszar edukacji szkolnej Drugiej Rzeczypospolitej. W jakim wymiarze się to udało i jakie przyniosło to efekty, nie jest łatwe do rozstrzygnięcia.

W literaturze interpretacyjnej przedmiotu, jak również w wypowiedziach osób okresu międzywojennego żywo zainteresowanych przenikaniem do edukacji idei wychowania katolickiego, odnajdujemy bardzo różne, czasami niezmiernie odmienne, oceny tego stanu rzeczy.

Pojawiają się opinie, iż wpływy pedagogiki chrześcijańskiej, w tym także edukacji religijnej dzieci i młodzieży, były w Drugiej Rzeczypospolitej zauważalne. Ową tezę głosił między innymi ówczesny kardynał Aleksander Kakowski, który w liście pasterskim skierowanym do wiernych z okazji 50lecia kapłaństwa pisał: ,szkoła w państwie polskim jest, chwała Bogu, z zasady na ogół religijna" ${ }^{"}$.

O silnym wpływie pedagogiki chrześcijańskiej na rzeczywistość edukacyjną wspominają między innymi $\mathrm{w}$ artykule $\mathrm{z}$ lat pięćdziesiątych XX wieku Zygmunt Mysłakowski i Ignacy Szaniawski ${ }^{90}$. Przywołują oni fakty, które ich zdaniem za tym przemawiają ${ }^{91}$.

${ }^{87}$ Por. J. Szczepaniak, Episkopat, s. 222-226.

${ }^{88}$ Por. tenże, Troska..., s. 275.

${ }^{89}$ Cyt. za: J. Macała, Z dyskusji o szkole katolickiej w II RP, „Polityka i Społeczeństwo” 3 (2006), s. 72. Zob. List Pasterski kard. Kakowskiego z okazji 50-lecia kapłaństwa.

90 Por. Z. Mysłakowski, I. Szaniawski, Pedagogika i oświata w Polsce w latach 19181939, „Nowa Szkoła” 5 (1950), s. 251-287.

${ }^{91}$ Por. tamże, s. 269-271. 
W tych refleksjach zauważamy jednak pewną tendencyjność ${ }^{22}$ przejawiającą się w ich niezgodzie na przenikanie idei pedagogiki chrześcijańskiej do polskiej rzeczywistości edukacyjnej i społecznej. Stąd też przerysowanie pewnych faktów, z jednoczesnym negatywnym ustosunkowaniem się do katolicyzmu. Wskazują oni, iż walka o katolicki ideał wychowawczy zaowocowała przenikaniem do programów szkolnych chrystocentryzmu, który określili mianem teorii nacjonalistyczno-dewocyjnej. Ich zdaniem forsowano ją pod płaszczykiem walki o apolityczną i ponadpartyjną szkołę i naukę, a „,w rzeczywistości stała się ona potężną bronią w ręku endeków i endekoidów oświatowych, dewotów i bigotów pedagogicznych, którzy pozostawali w walce z nauką i postępem" ${ }^{\prime 93}$. W pewnym sensie ich krytycyzm może wydawać się zasadny ${ }^{94}$. Czy jednak nie jest on przesadzony, a przede wszystkim niewłaściwie ukierunkowany w stronę katolickiego ideału wychowania?

Dość krytycznie do nurtu katolickiego, jako tego, który oddziaływał pozytywnie na życie społeczne, odnosi się też Feliks Araszkiewicz. Uznaje on, iż w teleologii wychowawczej był to w Drugiej Rzeczypospolitej nurt najbardziej arealistyczny, który najmniej kierował się polską racją stanu i dobrem kraju. Stwierdza przy tym, że „nie interesował [go - A.Z.] człowiek jako członek określonej wspólnoty narodowej i państwowej”, a jedynie „jako członek wspólnoty wyznaniowej"95.

Odnajdujemy też stwierdzenia, iż religia katolicka obecna w rzeczywistości edukacyjnej polskiej szkoły międzywyznaniowej czasów międzywo-

92 Leonard Grochowski zaznacza, iż wśród publikacji, w których poruszano problematykę wychowania religijnego w szkołach polskich okresu międzywojennego, znalazła się pewna grupa, tworzona przez ponad cztery dekady począwszy od zakończenia II wojny światowej, która wyróżnia się specyficzną warstwą interpretacyjną opartą na osobliwych założeniach metodologii badań i ideologii, co owocowało traktowaniem tej problematyki w niekorzystnym świetle: przez wskazywanie na wygórowane ambicje i roszczenia Kościoła lub też przypisywanie Kościołowi i wychowaniu religijnemu działań, mających na celu utrudnianie procesu wprowadzania zasady szkoły świeckiej oraz podejmowanie akcji dążących do klerykalizowania szkolnictwa. Do autorów grupy tej zalicza: Janinę Schoenbrenner, Bolesława Reinera, Feliksa Araszkiewicza czy Seweryna Gerusa. Zob. L. Grochowski, dz. cyt., s. 241-242.

93 Z. Mysłakowski, I. Szaniawski, dz. cyt., s. 270-271.

${ }^{94} \mathrm{~W}$ wypowiedziach duchowieństwa dotyczących edukacji szkolnej odnajdujemy niejednokrotnie takie, w których uwydatniano absolutną wartość religii katolickiej, podkreślając jej wyższość wobec innych wyznań, Kościołowi przypisywano wyłączność na posiadanie prawdy, zaś wyrazicieli innych poglądów nazywano bezbożnikami zwalczającymi religię i walczącymi z Bogiem. Nierzadko więc wyznawany przez narodowców katolicyzm i nacjonalizm mógł owocować negatywnymi postawami przejawiającymi się w nietolerancji wyznaniowej czy językowo-kulturowej dyskryminacji mniejszości narodowych. Por. L. Grochowski, dz. cyt., s. $248,256$.

${ }_{95}$ F. Araszkiewicz, dz. cyt., s. 263. 
jennych nie miała większego wpływu na wychowanie młodych ${ }^{96}$. Wynika to być może z faktu, że na drodze pozytywnego wpływu edukacji religijnej na humanizację życia społecznego stały jawne konflikty i nieporozumienia pojawiające się między Kościołem a różnymi instytucjami (państwem, partiami politycznymi, związkami zawodowymi nauczycieli) czy poszczególnymi osobami (ministrami i biskupami, politykami i duchownymi, prefektami i nauczycielami). Zachodziły one również na tle różnic w poglądach na temat obecności religii i Kościoła w szkole czy też obowiązującej doktryny wychowawczej.

Do ostrych polemik dochodziło przez cały okres międzywojenny, głównie między Kościołem a lewicą społeczno-polityczną, oświatową czy nauczycielską. Ta wzajemna niechęć i opozycja wynikała z odmiennych dążeń oświatowych. Kościół, pragnąc utrzymać swój wpływ na całokształt wychowania szkolnego, rzucał wobec nauczycieli związanych z lewicą pomówienia o niemoralność, bezbożnictwo czy bolszewizm. Lewica zaś, dążąc do zminimalizowania wpływu kleru na wychowanie szkolne i wprowadzenia szkoły laickiej, określała Kościół mianem zacofanej i pełnej praktyk dewocyjnych instytucji, sprzeciwiającej się wszelkiemu postępowi i wolnej myśli. Wzajemne zarzuty były stanowczo przejaskrawione, bezzasadne, a przede wszystkim miały bardzo negatywny wymiar wychowawczy ${ }^{97}$. W obliczu tych sporów, w których obie strony dopuszczały się tak ostrych i niejednokrotnie niesłusznych ocen wobec siebie nawzajem, trudno mówić o pozytywnym wymiarze edukacji religijnej w sferze humanizacji życia społecznego.

Silnym echem odbiły się również nieporozumienia między Kościołem a rządem sanacyjnym, głównie w związku z określeniem miejsca wychowania religijnego w systemie wychowania państwowego ${ }^{98}$. Wprawdzie wśród sanacyjnych działaczy oświatowych byli tacy, którzy pragnęli oprzeć wychowanie państwowe na zasadach katolickich, ale również i tacy, którzy zakładali, iż źródłem wszelkiego prawa jest wyłącznie państwo i nie da się pogodzić wychowania religijnego z państwowym ${ }^{99}$.

Jednym z obszarów narastających konfliktów była sprawa katolickiego charakteru polskiej szkoły. Biskupi wyrażali swe niezadowolenie z zapisów konstytucji, w której zrównano religię katolicką z innymi wyznaniami oraz nie uwzględniono postulatu szkoły wyznaniowej. Wielokrotnie w latach

${ }^{96}$ Por. J. Macała, dz. cyt., s. 72.

${ }^{97}$ Por. L. Grochowski, dz. cyt., s. 261-262.

98 Szczegółowo problematykę tę podejmuje Jan Szczepaniak, Episkopat, s. 270. Częściowo zagadnienie to omawia również Stanisław Wilk, Episkopat Kościoła katolickiego w Polsce w latach 1918-1939, Warszawa 1992, s. 281-304.

99 Por. J. Szczepaniak, Episkopat, s. 67-72. 
1929-1937 przedkładali oni władzom państwowym swą niezgodę na tworzenie szkół mieszanych, prosząc o wydanie stosownych zarządzeń, dzięki którym nie dochodziłoby do mieszania dzieci katolickich z dziećmi innowierczymi i aby dzieci katolickie były wychowywane jedynie przez nauczycieli katolickich. Nie spotkało się to ze zrozumieniem ze strony Ministerstwa WRiOP, a zdarzały się przypadki, iż celowo mieszano dzieci różnych wyznań w jednej szkole ${ }^{100}$. Niestety, doprowadzało to czasami do ostrych komentarzy ze strony hierarchii Kościoła ${ }^{101}$, co nie służyło budowaniu porozumienia i nie wpływało pozytywnie na tworzenie ładu społecznego.

Innym obszarem pogłębiającego się podziału Kościoła i państwa była sprawa koedukacji, w zdecydowanej większości nie akceptowana przez biskupów i działaczy katolickich ${ }^{102}$. Wprowadzanie zaś koedukacji bez zachowywania obowiązujących rozporządzeń oświatowych doprowadziło w latach 1935-1937 do oporu społeczności katolickiej i zorganizowania wieców, na których rodzice przeciwstawiali się niezgodnym z prawem działaniom władz szkolnych ${ }^{103}$.

Do szczególnego zaognienia stosunków pomiędzy rządem a Kościołem doszło po 1932 roku, a ich normalizacja nastapiła dopiero z początkiem 1937 roku, za rządów ministra WRiOP Wojciecha Alojzego Świętosławskiego ${ }^{104}$, który w swoich przemówieniach sejmowych zaznaczał, iż ,,wszczepienie zasad głębokiej etyki i moralności jest do osiagnięcia jedynie przez religijne wychowanie młodych pokoleń" ${ }^{105}$. Do wybuchu II wojny światowej nie pozostało już jednak wiele czasu, więc jakie to miało przełożenie na rzeczywistość edukacyjna, pozostanie raczej w sferze niewiadomej.

Te długotrwałe spory, pomimo przywoływanego wcześniej, pozytywnego potencjału, jaki niesie w sobie edukacja religijna w kontekście humanizacji życia społecznego oraz nieustannej obecności tej edukacji w rzeczywistości szkolnej dzieci i młodzieży Drugiej Rzeczypospolitej, wywoływały pewne napięcia. To nie tylko burzyło harmonię współżycia społecznego wśród

100 Por. tamże, s. 77-88.

101 Przykładowo ordynariusz przemyski bp Józef Pelczar w liście pasterskim używał dość mocnych sformułowań skierowanych do posłów i nauczycieli: „Nie brak nawet zaprzańców, którzy odurzeni pychą, rozpustą czy nienawiścią do kapłanów, wyrzekli się wiary katolickiej i tę wiarę innym duszom wydzierają; a tę misję iście diabelską spełniają szczególnie pisma socjalistyczne i radykalne. Stąd baczność przed niemi, jak przed jadowitymi wężami”. Cyt. za: tamże, s. 78-79.

102 Por. tamże, s. 89-97.

103 Do takich wieców doszło m.in. w Rakowie, Lwowie, Grudziądzu. Por. tamże, s. 94-96.

\footnotetext{
104 Por. tamże, s. 140-143.

105 Cyt. za: S. Wilk, dz. cyt., s. 303-304.
} 
dorosłych, ale mogło mieć również negatywny pedagogiczny wydźwięk ukierunkowany wobec dzieci i młodzieży.

Niezależnie jednak od wyłaniającego się tu pesymistycznego obrazu nie można zapominać, że w czasach porozbiorowych potrzeba było wychowania, które określałoby jednoznacznie kryteria dobra i zła, jako niezwykle istotnego wykładnika humanizacji życia społecznego. Wydaje się, że właśnie edukacja religijna dwudziestolecia międzywojennego spełniała te warunki w stu procentach przez przekazywanie jasnych i niezmiennych prawd oraz wyraźnych postaw moralnych, osadzonych na Bożych przykazaniach i Chrystusie jako wzorcu pełnego człowieczeństwa. Abstrahując więc od powstających wątpliwości, czy szkolna edukacja religijna Drugiej Rzeczypospolitej w znacznym stopniu oddziaływała na tworzenie ładu społecznego, pojawia się nadzieja, że ten pozytywny wpływ w jakimś stopniu zaistniał. Wynika ona również z faktu, że duszpasterstwo religijne, ukierunkowane na oparcie relacji międzyludzkich na miłości i sprawiedliwości, prowadzone było także poza szkoła, w spokojnej atmosferze, zaś oddziaływanie skierowane było wobec dzieci i młodzieży, których rodzice w całej pełni hołdowali tym samym ideałom co katecheci, a to niewątpliwie wpływało na podwyższenie efektów oddziaływań pedagogicznych.

\section{Religious Education of Young Children and Teenagers during the Interwar Period as the Source of Humanization of Social Life (Summary)}

There is no doubt that the Catholic doctrine played an important role in the educational reality of the interwar period and it was considered a vital element in the reconstruction of social order and the humanization of mass culture. Was it truly the source of humanization of social life in the Second Republic of Poland? The above question is the main presumption in this research. The undertaken analysis is outlined by two main assumptions. Firstly, it presents the social value of the process of education and religious instruction in beliefs of contemporary promoters of religious education. Secondly, it discusses various forms of religious education (catholic schools activities, the presence of religious education and practices in the national curriculum, functioning of religious youth school organisations) and their influence on young children and teenagers. Finally, it attempts to find out if the process of religious education benefited the social life with reference to the engrossing conflict between the Catholic Church and the state government in the interwar period over the methods of religious education. 